\title{
MOLECULAR DESCRIPTION OF COPPER(II) OXIDE
}

\author{
Wei Gao ${ }^{1^{*}}$, Abdul Qudair Baig ${ }^{2}$, Waqas Khalid ${ }^{2}$, Mohammad Reza Farahani ${ }^{3}$ \\ ${ }^{1}$ School of Information Science and Technology, Yunnan Normal University, Kunming 650500, China \\ ${ }^{2}$ Department of Mathematics, COMSATS Institute of Information Technology, Attock Campus, Pakistan \\ ${ }^{3}$ Department of Applied Mathematics, Iran University of Science and Technology, \\ Narmak, 16844, Tehran, Iran
}

gaowei@ynnu.edu.cn, aqbaig1@gmail.com,waqas.khalid38@gmail.com, mrfarahani88@gmail.com

Graph theory has much advancement in the field of mathematical chemistry. Recently, chemical graph theory has become very popular among researchers because of its wide applications in mathematical chemistry. The molecular topological descriptors are the numerical invariants of a molecular graph and are very useful for predicting their bioactivity. A great variety of such indices are studied and used in theoretical chemistry, pharmaceutical researchers, in drugs and in different other fields.

In this article, we study the chemical graph of copper oxide and compute degree based topological indices mainly $\mathrm{ABC}, \mathrm{GA}, \mathrm{ABC}_{4}, \mathrm{GA}_{5}$, general Randić index and Zagreb index for copper(II) oxide, $\mathrm{CuO}$. Furthermore, we give exact formulas of these indices which are helpful in studying the underlying topologies.

Keywords: molecular descriptor; copper(II) oxide; atom bond connectivity index; geometric arithmetic index; general Randić index; Zagreb index; $\mathrm{ABC}_{4} ; \mathrm{GA}_{5}$

\section{МОЛЕКУЛСКИ ДЕСКРИПТОРИ ЗА БАКАР(ІІ) ОКДСИД}

Теоријата на графови има голем напредок на полето на математичката хемија. Од неодамна, хемиската теорија на графови е особено интересна меѓу истражувачите поради широката примена во математичката хемија. Молекулските тополошки дескриптори се нумерички инваријанти на молекулскиот граф и се многу корисни за претскажување на нивната биоактивност. Голем број на вакви индекси се истражуваат и се применуваат во теориската хемија, фармацевтските истражувања на лекови и на други полиња.

Во овој труд го изучивме хемискиот граф на бакар оксид и ги пресметавме тополошките индекси засновани на агли, имено $\mathrm{ABC}, \mathrm{GA}, \mathrm{ABC}_{4}, \mathrm{GA}_{5}$, општиот Рандиќев индекс и Загрепскиот индекс за бакар оксид, $\mathrm{CuO}$. Покрај тоа, ги наведуваме точните формули на овие индекси кои се од интерес за изучување на нивната основна топологија.

Клучни зборови: молекулски дескриптори; бакар(II) оксид; индекс на конективност на атомските врски; геометриски аритметички индекс; општ индекс на Рандиќ; Загрепски индекс; $\mathrm{ABC}_{4} ; \mathrm{GA}_{5}$.

\section{INTRODUCTION}

There are a lot of chemical compounds, either organic or inorganic, which possess a level of commercial, industrial, pharmaceutical chemistry and laboratory importance. A relationship exists between chemical compounds and their molecular structures. Graph theory is a very powerful area of mathematics that has wide range of applications in many areas of science such as chemistry, biology, computer science, electrical, electronics and other fields. The manipulation and examination of chem- 
ical structural information is made conceivable using molecular descriptors. Chemical graph theory is a branch of mathematical chemistry in which we apply tools of graph theory to model the chemical phenomenon mathematically. Furthermore, it relates to the nontrivial applications of graph theory for solving molecular problems. This theory contributes a prominent role in the field of chemical sciences.

Chem-informatics is new subject which is a combination of chemistry, mathematics and information science. It examines (QSAR) and (QSPR) relationships that are utilized to foresee the biological activities and physiochemical properties of chemical compounds. A lot of research in the field of chemical graph theory has been performed and researchers continue to research into this field. Some references are given, which hopefully demonstrate the importance of this field [13-15, $18-20,22,25-27,29]$. A chemical graph is a simple finite graph in which vertices denote the atoms and edges denote the chemical bonds in underlying chemical structure. A topological index is a numeric quantity associated with chemical constitution indicating for correlation of chemical structure with many physical, chemical properties and biological activities.

The rapid increase in the diseases and environmental problems in our ecosystem gives rise to increasing the physical and mental health problems of animals and human beings. Side by side, medicine manufacturing organizations and industries play their role to overcome diseases. The World Health Organization (WHO) and certain institutions play a role in improving environmental and health problems. A large number of medicines and drug products are produced each year. In order to determine the chemical properties of such medicines and drugs, we focus on theoretical examination of the topological indices. Chemists need to understand the bioactivities and chemical properties of drugs. The forgotten topological indices of some drug structures and chemical structures in drugs are computed in $[12,16]$. The smart polymer family is widely used in anticancer drugs and some of its topological indices are computed in [7].

Let $\mathrm{G}=(\mathrm{V}, \mathrm{E})$ be a graph where $\mathrm{V}$ be the vertex set and $\mathrm{E}$ be the edge set of $\mathrm{G}$. The degree $\operatorname{deg}(\mathrm{v})\left(\right.$ or $\left.=\mathrm{d}(\mathrm{v})=\mathrm{d}_{\mathrm{v}}\right)$ of $\mathrm{v}$ is the number of edges of $G$ incident with $v$. The distance $d(u, v)$ of a graph $\mathrm{G}$ is defined as the shortest length between $\mathrm{u}$ and $\mathrm{v}$.

The concept of topological index came from work done by Wiener in 1947 while he was working on boiling point of paraffin [33]. Later on, the theory of topological indices started. Let $\mathrm{G}$ be a graph then Wiener index is defined as:

$$
W(G)=\frac{1}{2} \sum_{u, v \in V(G)} d(u, v) .
$$

There are certain types of degree based topological indices. Some of them that are used in this article are defined below.

One of the first and oldest degree-based indices was introduced by Milan Randić [28] in 1975 and is defined below:

$$
R_{\frac{-1}{2}}(G)=\sum_{u v E(G)} \frac{1}{\sqrt{d_{u} d_{v}}} .
$$

In 1988, Bollobas et al. [2] and Amic et al. [1] proposed the general Randić index independently. For more details about the Randić index, its properties and important results see $[5,21$, 24]. The general Randić index is defined as:

$$
R_{\alpha}(G)=\sum_{u v \in E(G)}\left(\sqrt{d_{u} d_{v}}\right)^{\alpha} .
$$

One of the important degree-based topological indices is the first Zagreb index. It was introduced in 1972 by [11]. Later on, the second Zagreb index was introduced by [10]. Both the first and second Zagreb indices are formulated as:

$$
\begin{gathered}
M_{1}(G)=\sum_{u v E(G)}\left(d_{u}+d_{v}\right) . \\
M_{2}(G)=\sum_{u v \in E(G)}\left(d_{u} d_{v}\right) .
\end{gathered}
$$

Among the degree-based topological indices, the atom bond connectivity index is of vital importance; this was introduced by Estrada et al. [6] and is defined as:

$$
A B C(G)=\sum_{u v \in(G)} \sqrt{\frac{d_{u}+d_{v}-2}{d_{u} d_{v}}} .
$$

where $d_{u}$ is the degree of vertex $u$.

A well-known topological index fourth version of atom bond connectivity index $\mathrm{ABC}_{4}$ of a graph $\mathrm{G}$ is introduced by Ghorbani et al. [8] and is defined as:

$$
A B C_{4}(G)=\sum_{u v \in E(G)} \sqrt{\frac{S_{u}+S_{v}-2}{S_{u} S_{v}}} .
$$

where $S_{u}=\sum_{u v \in E(G)} d_{v}$ and $S_{v}=\sum_{u v \in E(G)} d_{u}$. 
The geometric arithmetic index $G A$ of a graph $G$ is introduced by Vukičević et al. [31] and is defined as:

$$
G A(G)=\sum_{u v \in E(G)} \frac{2 \sqrt{d_{u} d_{v}}}{d_{u}+d_{v}} .
$$

Another well-known topological descriptor fifth version of geometric arithmetic index $\mathrm{GA}_{5}$ of a graph $\mathrm{G}$ was introduced by Graovac et al. [9] and is defined as:

$$
G A_{5}(G)=\sum_{u v \in(G)} \frac{2 \sqrt{S_{u} S_{v}}}{S_{u}+S_{v}} .
$$

a

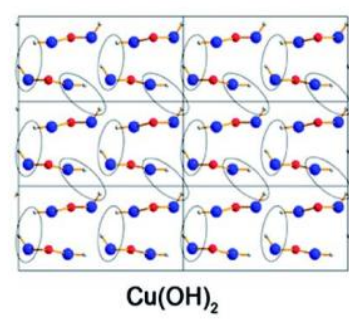

i) $\mathrm{Cu}(\mathrm{OH})_{2} \rightarrow \mathrm{CuO}+\mathrm{H}_{2} \mathrm{O}$ b

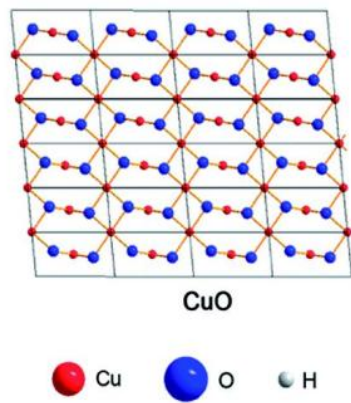

Fig. 1. (a) $\mathrm{Cu}(\mathrm{OH})_{2}$, (b) $\mathrm{CuO}$

\section{COPPER(II) OXIDE}

In this section, some history about copper oxide is described and related applications to copper and copper oxide are provided in the form of references and the references therein. The copper(II) oxide (cupric oxide) form an inorganic chemical compound $\mathrm{CuO}$. This is an essential mineral found in plants and animals. Copper has enormous applications in medical instruments, drugs, and as a heat conductor, among others. Some applications of copper and cupric oxide are given in $[3,17,23,30]$.

In Figure 1(a), the copper hydroxide is depicted and when hydrogen atoms are depleted from $\mathrm{Cu}(\mathrm{OH})_{2}$ then the resultant graph is depicted in Figure 1(b). The 3D graph of $\mathrm{CuO}$ is depicted in Figure 2. Copper(II) oxide is used as the source of copper in mineral and vitamin supplements and is considered safe. Its use in medical devices, and industrial and consumer products, is novel. The safety aspects of the use of copper(II) oxide in products that come into contact with open and closed skin must be considered [4].

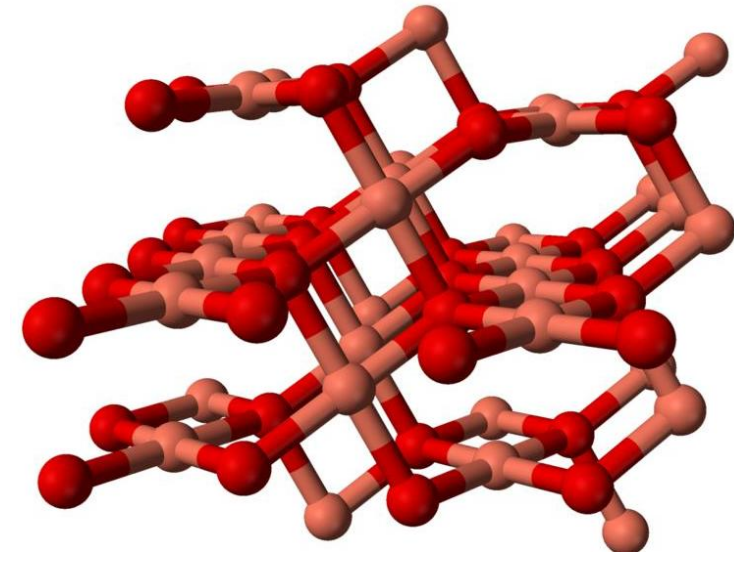

Fig. 2. 3D Copper(II) oxide

\section{MAIN RESULTS}

In this section, we compute topological indices; mainly the atom bond connectivity index, geometric arithmetic index, $\mathrm{ABC}_{4}, \mathrm{GA}_{5}$, general Randić indices and Zagreb indices of copper(II) oxide. Furthermore, we compute close formulas of these indices for $\mathrm{CuO}$. A topological index can give us chemical information that is related to the chemical graph. It provides a numerical number which is helpful in (QSAR=QSPR) studies.

In this article, we consider the copper(II) oxide molecular graph $\mathrm{CuO}$, as depicted in Figure 1(b). The construction of the $\mathrm{CuO}$ graph is such that the octagons are connected to each other in columns and rows; the connection between two octagons is achieved by making one $\mathrm{C}_{4}$ bond between two octagons. For our convenience, we take $m$ and $n$ as the number of octagons in rows and columns, respectively. The cardinality of vertices and edges in $\mathrm{CuO}$ are $4 m n+3 n+m$ and $6 m n+2 n$ respectively. In $\mathrm{CuO}$, the 2 degree vertices are $m n+5 n+2 m$, the 3 degree vertices are $2 m n-2 n$ and 4 degree vertices are $m n-m$.

A close result formula of atom bond connectivity index for $\mathrm{CuO}$ is computed in the following theorem.

Table 1

Edge partition of $\mathrm{CuO}$ graph based on degrees of end vertices of each edge

\begin{tabular}{cc}
\hline \hline $\boldsymbol{d}_{\boldsymbol{u}}, \boldsymbol{d}_{\boldsymbol{v}}$ & Frequency \\
\hline$(2,2)$ & $4(n+1)$ \\
$(2,3)$ & $2 m n+2(2 m-n)-4$ \\
$(2,4)$ & $4(n-1)$ \\
$(3,4)$ & $4(m n-(m+n)+1)$ \\
\hline \hline
\end{tabular}


Theorem 3.1. Consider the graph of $\mathrm{G}=$ $\mathrm{CuO}$ with $m ; n>1$, then its atom bond connectivity index is equal to:

$$
\begin{gathered}
A B C(G)=m\left(2 \sqrt{2}-\frac{2 \sqrt{15}}{3}\right)+n\left(3 \sqrt{2}-\frac{2 \sqrt{15}}{3}\right)+ \\
+m n\left(\sqrt{2}-\frac{2 \sqrt{15}}{3}\right)-\left(2 \sqrt{2}-\frac{2 \sqrt{15}}{3}\right) .
\end{gathered}
$$

Proof. We prove the above result by using Table 1 in the formula of atom bond connectivity index.

$$
A B C(G)=\sum_{u v \in E(G)} \sqrt{\frac{d_{u}+d_{v}-2}{d_{u} d_{v}}} .
$$

The following table shows the edge set partition of $\mathrm{G}=\mathrm{CuO}$ :

$A B C(G)=4(n+1) \sqrt{\frac{2+2-2}{2 \times 2}}+(2 m n+2(2 m-n)-4) \sqrt{\frac{2+3-2}{2 \times 3}}$

$+4(n-1) \sqrt{\frac{2+4-2}{2 \times 4}}+4(m n-(m+n)+1) \sqrt{\frac{3+4-2}{3 \times 4}}$.

After simplification and rearranging the terms, we get:

$$
\begin{aligned}
A B C(G) & =m\left(2 \sqrt{2}-\frac{2 \sqrt{15}}{3}\right)+n\left(3 \sqrt{2}-\frac{2 \sqrt{15}}{3}\right)+ \\
+ & m n\left(\sqrt{2}+\frac{2 \sqrt{15}}{3}\right)-\left(2 \sqrt{2}+\frac{2 \sqrt{15}}{3}\right) .
\end{aligned}
$$

A close result formula of the geometric arithmetic index for $\mathrm{CuO}$ is computed in the following theorem.

Theorem 3.2. Consider the graph of $\mathrm{G}=$ $\mathrm{CuO}$ with $m ; n>1$, then its geometric arithmetic index is equal to

$$
\begin{gathered}
G A(G)=m\left(-\frac{16 \sqrt{3}}{7}+\frac{8 \sqrt{6}}{5}\right)+ \\
+n\left(\frac{8 \sqrt{2}}{3}-\frac{16 \sqrt{3}}{7}-\frac{4 \sqrt{6}}{5}+4\right)+ \\
+m n\left(\frac{16 \sqrt{3}}{7}+\frac{4 \sqrt{6}}{5}\right)+\left(-\frac{8 \sqrt{2}}{3}+\frac{16 \sqrt{3}}{7}-\frac{8 \sqrt{6}}{5}+4\right) .
\end{gathered}
$$

Proof. We prove the above result by using Table 1 in the formula of a geometric arithmetic index.

$$
\begin{gathered}
G A(G)=\sum_{u v \in(G)} \frac{2 \sqrt{d_{u} d_{v}}}{d_{u}+d_{v}}= \\
=4(n+1) \frac{2 \sqrt{2 \times 2}}{2+2}+(2 m n+2(2 m-n)-4) \frac{2 \sqrt{2 \times 3}}{2+3}+ \\
+4(n-1) \frac{2 \sqrt{2 \times 4}}{2+4}+4(m n-(m+n)+1) \frac{2 \sqrt{3 \times 4}}{3+4} .
\end{gathered}
$$

After simplification and rearranging the terms, we get:

$$
\begin{gathered}
G A(G)=m\left(-\frac{16 \sqrt{3}}{7}+\frac{8 \sqrt{6}}{5}\right)+ \\
+n\left(\frac{8 \sqrt{2}}{3}-\frac{16 \sqrt{3}}{7}-\frac{4 \sqrt{6}}{5}+4\right)+ \\
+m n\left(\frac{16 \sqrt{3}}{7}+\frac{4 \sqrt{6}}{5}\right)-\frac{8 \sqrt{2}}{3}+\frac{16 \sqrt{3}}{7}-\frac{8 \sqrt{6}}{5}+4 .
\end{gathered}
$$

A close result formula of general Randić index for $\mathrm{CuO}$ is computed in the following theorem.

Theorem 3.3. Consider the graph of $\mathrm{G}=$ $\mathrm{CuO}$ with $m ; n>1$, then its general Randić index is equal to

$$
R_{\alpha}(G)=\left\{\begin{array}{lr}
60 m n-12(2 m+n)+8, & \text { if } \alpha=1, \\
\frac{1}{6}(4 m n+2 m+5 n+1), & \alpha=-1, \\
m\left(\frac{4 \sqrt{3}-2 \sqrt{6}}{3 \sqrt{2}}\right)+n\left(\frac{2 \sqrt{3}+2 \sqrt{6}-2}{\sqrt{6}}\right)+2 m n\left(\frac{\sqrt{3}+\sqrt{6}}{3 \sqrt{2}}\right) & \text { if } \alpha=\frac{-1}{2}, \\
+\left(\frac{6 \sqrt{2}+4 \sqrt{3}+2 \sqrt{6}-6}{3 \sqrt{2}}\right), & \\
m(-8 \sqrt{3}+4 \sqrt{6})+n(8 \sqrt{2}-8 \sqrt{3}-2 \sqrt{6}+8) & \text { if } \alpha=\frac{1}{2} . \\
+m n(8 \sqrt{3}+2 \sqrt{6})-8 \sqrt{2}+8 \sqrt{3}-4 \sqrt{6}+8, &
\end{array}\right.
$$

Proof. Let $\mathrm{G}$ be a graph of $\mathrm{CuO}$. To prove the above result, we use Table 1 in general Randić index formula with $=1$.

$$
\begin{gathered}
R_{1}(G)=\sum_{u v \in E(G)}\left(d_{u} \times d_{v}\right)= \\
=4(n+1)(2 \times 2)+(2 m n+2(2 m-n)-4)(2 \times 3)+ \\
+4(n-1)(2 \times 4)+4(m n-(m-n)+1)(3 \times 4)= \\
=60 m n-12(2 m+n)+8 .
\end{gathered}
$$

For $\alpha=-1$, the formula of Randić index takes the following form: 


$$
\begin{gathered}
R_{-1}(G)=\sum_{u v \in E(G)} \frac{1}{\left(d_{u} \times d_{v}\right)}= \\
=4(n+1) \frac{1}{(2 \times 2)}+(2 m n+(2 m-n)-4) \frac{1}{(2 \times 3)} \\
+4(n-1) \frac{1}{(2 \times 4)}+4(m n-(m+n)+1) \frac{1}{(3 \times 4)}= \\
=\frac{1}{6}(4 m n+2 m+5 n+1) .
\end{gathered}
$$

For $\alpha=\frac{1}{2}$, the formula of Randić index takes the following form:

$$
\begin{gathered}
R_{\frac{1}{2}}(G)=\sum_{u v \in E(G)} \sqrt{\left(d_{u} \times d_{v}\right)}= \\
=4(n+1) \sqrt{(2 \times 2)}+ \\
+(2 m n+2(2 m-n)-4) \sqrt{(2 \times 3)}+ \\
+4(n-1) \sqrt{(2 \times 4)}+ \\
+4(m n-(m+n)+1) \sqrt{(3 \times 4)}= \\
=m(-8 \sqrt{3}+4 \sqrt{6})+n(8 \sqrt{2}-8 \sqrt{3}-2 \sqrt{6}+8)+ \\
+m n(8 \sqrt{3}+2 \sqrt{6})-8 \sqrt{2}+8 \sqrt{3}-4 \sqrt{6}+8 .
\end{gathered}
$$

For $\alpha=\frac{-1}{2}$, the formula of Randić index takes the following form:

$$
\begin{gathered}
R_{\frac{-1}{2}}(G)=4(n+1) \frac{1}{\sqrt{(2 \times 2)}}+ \\
+(2 m n+2(2 m-n)-4) \frac{1}{\sqrt{(2 \times 3)}}+ \\
+4(n-1) \frac{1}{\sqrt{(2 \times 4)}}+4(m n-(m+n)+ \\
+1) \frac{1}{\sqrt{(3 \times 4)}}= \\
+2 m n\left(\frac{4 \sqrt{3}-2 \sqrt{6}}{3 \sqrt{2}}\right)+n\left(\frac{2 \sqrt{3}+2 \sqrt{6}-2}{3 \sqrt{6}}\right)+\left(\frac{6 \sqrt{2}+4 \sqrt{3}+2 \sqrt{6}-6}{3 \sqrt{2}}\right) .
\end{gathered}
$$

In the following theorem, we compute close results of first and second Zagreb indices for $\mathrm{CuO}$.

Theorem 3.4. Consider the graph $\mathrm{G}=\mathrm{CuO}$, for $\mathrm{m} ; \mathrm{n}>1$, then its first and second Zagreb index is equal to

$$
\begin{gathered}
M_{l}(G)=2(n-4 m+19 m n), \\
M_{2}(G)=60 m n-12(2 m+n)+8 .
\end{gathered}
$$

Proof. Let G be a graph of copper(II) oxide. The first Zagreb index can be calculated by using Table 1 in following equation.

$$
\begin{gathered}
M_{1}(G)=\sum_{u v \in E(G)}\left(d_{u}+d_{v}\right)= \\
=4(n-1)(4)+(2 m n+2(2 m-n)-4(5)+ \\
+4(n-1)(6)+4(m n-(m+n)+1)(7)= \\
=2(n-4 m+19 m n) .
\end{gathered}
$$

The second Zagreb index can be calculated by using Table 1 . in the following equation:

$$
\begin{gathered}
M_{2}(G)=\sum_{u v \in E(G)}\left(d_{u}+d_{v}\right) \\
=4(n-1)(4)+(2 m n+2(2 m-n)-4(6) \\
+4(n-1)(8)+4(m n-(m+n)+1)(12) \\
=60 m n-12(2 m+n)+8 .
\end{gathered}
$$

A close result formula of the fifth geometric arithmetic index for $\mathrm{CuO}$ is computed in the following theorem.

Theorem 3.5. Consider the graph of $\mathrm{G}=$ $\mathrm{CuO}$ with $m \geq 3$ and $n>2$, then its fifth geometric arithmetic index is equal to

$$
\begin{gathered}
G A_{5}(G)=m\left(6-\frac{\sqrt{15}}{2}-\frac{8 \sqrt{30}}{11}\right)+ \\
+n\left(4+\frac{8 \sqrt{6}}{5}+\frac{\sqrt{15}}{2}-\frac{16 \sqrt{30}}{11}\right)+ \\
+m n\left(\frac{\sqrt{15}}{2}-\frac{8 \sqrt{30}}{11}\right)+ \\
+\left(\frac{16 \sqrt{5}}{9}-\frac{8 \sqrt{6}}{5}-\frac{\sqrt{15}}{2}+\frac{24 \sqrt{30}}{11}-10\right)
\end{gathered}
$$


Table 2

Edge partition of $\mathrm{CuO}$ graph based on degree sum of end vertices of each edge

\begin{tabular}{cc}
\hline \hline$\left(\boldsymbol{S}_{u}, \boldsymbol{S}_{\boldsymbol{v}}\right)$ & Frequency \\
\hline$(4,4)$ & 4 \\
$(4,5)$ & 4 \\
$(4,6)$ & $4(n-1)$ \\
$(5,6)$ & 4 \\
$(6,6)$ & $6 m-10$ \\
$(6,10)$ & $2(m n-(m-n)-1)$ \\
$(10,10)$ & $4(n-1)$ \\
$(10,12)$ & $4(m n-(m+2 n)+2)$ \\
\hline \hline
\end{tabular}

Proof. We prove the above result by using Table 2 in the formula of the fifth geometric arithmetic index.

$$
\begin{gathered}
G A_{5}(G)=\sum_{u v \in E(G)} \frac{2 \sqrt{S_{u} S_{v}}}{S_{u}+S_{v}}= \\
=4 \frac{2 \sqrt{4 \times 4}}{4+4}+4 \frac{2 \sqrt{4 \times 5}}{4+5}+4(n-1) \frac{2 \sqrt{4 \times 6}}{4+6}+4 \frac{2 \sqrt{5 \times 6}}{11} \\
+(6 m-10) \frac{2 \sqrt{6 \times 6}}{6+6}+2(m n-(m-n)-1) \frac{2 \sqrt{6 \times 10}}{6+10} \\
+4(n-1) \frac{2 \sqrt{10 \times 10}}{10+10}+4(m n-(m+2 n)+2) \frac{2 \sqrt{10 \times 12}}{10+12}
\end{gathered}
$$

After simplification and rearranging the terms, we get

$$
\begin{aligned}
& G A_{5}(G)=m\left\{6-\frac{\sqrt{15}}{2}-\frac{8 \sqrt{30}}{11}\right\}+n\left\{4+\frac{8 \sqrt{6}}{5}+\frac{\sqrt{15}}{2}-\frac{16 \sqrt{30}}{11}\right\} \\
& +m n\left\{\frac{\sqrt{15}}{2}+\frac{8 \sqrt{30}}{11}\right\}+\frac{16 \sqrt{5}}{9}-\frac{8 \sqrt{6}}{5}-\frac{\sqrt{15}}{2}+\frac{24 \sqrt{30}}{11}-10 .
\end{aligned}
$$

A close result formula of fourth atom bond connectivity index for $\mathrm{CuO}$ is computed in the following theorem.

Theorem 3.6. Consider the graph of $\mathrm{G}=\mathrm{CuO}$ with $m \geq 3$ and $n>2$, then its fourth atom bond connectivity index is equal to:

$$
\begin{gathered}
A B C_{4}(G)=m\left(\sqrt{10}-\frac{\sqrt{210}}{15}-\frac{4}{\sqrt{6}}\right)+ \\
+n\left(\frac{6 \sqrt{2}}{5}+\frac{4}{\sqrt{3}}+\frac{\sqrt{210}}{15}-\frac{8}{\sqrt{6}}\right)+
\end{gathered}
$$

$$
\begin{gathered}
+m n\left(\frac{\sqrt{210}}{15}+\frac{4}{\sqrt{6}}\right)+ \\
+\left(\frac{6 \sqrt{2}}{5}-\frac{4}{\sqrt{3}}+\frac{14}{\sqrt{6}}-\frac{5 \sqrt{10}}{3}+\frac{2 \sqrt{30}}{5}+\frac{2 \sqrt{35}}{5}-\frac{\sqrt{210}}{15}\right) .
\end{gathered}
$$

Proof. We prove the above result by using Table 2 in the formula of fourth atom bond connectivity index.

$$
\begin{gathered}
A B C_{4}(G)=\sum_{u v \in E(G)} \sqrt{\frac{S_{u}+S_{v}-2}{S_{u} S_{v}}} \\
=4 \sqrt{\frac{4+4-2}{4 \times 4}}+4 \sqrt{\frac{4+5-2}{4 \times 5}}+ \\
+4(n-1) \sqrt{\frac{4+6-2}{4 \times 6}}+4 \sqrt{\frac{5+6-2}{5 \times 6}}+ \\
+(6 m-10) \sqrt{\frac{6+6-2}{6 \times 6}+} \\
+2\left(m n-(m-n)-1 \sqrt{\frac{6+10-2}{6 \times 10}}+\right. \\
+4(n-1) \sqrt{\frac{10+10-2}{10 \times 10}+4(m n-(m+2 n)+} \\
+2 \sqrt{\frac{10+12-2}{10 \times 12}}
\end{gathered}
$$

After simplification and rearranging the terms, we get:

$$
\begin{aligned}
& A B C_{4}(G)=m\left\{\sqrt{10}-\frac{\sqrt{210}}{15}-\frac{4}{\sqrt{6}}\right\}+n\left\{\frac{6 \sqrt{2}}{5}+\frac{4}{\sqrt{3}}+\frac{\sqrt{210}}{15}-\frac{8}{\sqrt{6}}\right\} \\
& +m n\left\{\frac{\sqrt{210}}{15}+\frac{4}{\sqrt{6}}\right\}-\frac{6 \sqrt{2}}{5}-\frac{4}{\sqrt{3}}+\frac{14}{\sqrt{6}}-\frac{5 \sqrt{10}}{3}+\frac{2 \sqrt{30}}{5}+\frac{2 \sqrt{35}}{5}-\frac{\sqrt{210}}{15} .
\end{aligned}
$$

\section{CONCLUSION}

In this paper, we have computed some degree-based topological indices for the chemical graph copper(II) oxide, $\mathrm{CuO}$. Exact and close results were shown for the atom bond connectivity index $\mathrm{ABC}$, geometric arithmetic index GA, general Randić index, $\mathrm{GA}_{5}$ and $\mathrm{ABC}_{4}$, Zagreb indices for $\mathrm{CuO}$. These results are fruitful and helpful in understanding the topological properties of cupric oxide. In the future, we are interested in sketching 
and designing some new chemical graphs and examining their underlying topological properties.

\section{REFERENCES}

[1] D. Amic, D. Beslo, B. Lucić, S. Nikolić, N. Trinajstić, The vertex-connectivity index revisited, J. Chem. Inf. Comput. Sci., 38, 819-822 (1998).

[2] B. Bollobas, P. Erdos, Graphs of extremal weights, Ars Combinatoria, 50, 225-233 (1998).

[3] G. Borkow, Using copper to improve the well-being of the skin, Current Chemical Biology, 8, 89-102 (2014).

[4] G. Borkow, Safety of using copper oxide in medical devices and consumer products, Current Chemical Biology, 6 (1), 86-92 (2012). DOI: 10.2174/2212796811206010086.

[5] G. Caporossi, I. Gutman, P. Hansen, L. Pavlovic, Graphs with maximum connectivity index, Comput. Bio. Chem., 27, 85-90 (2003).

[6] E. Estrada, L. Torres, L. Rodriguez, I. Gutman, An atom-bond connectivity index: Modeling the enthalpy of formation of alkanes, Indian J. Chem., 37A, 849-855 (1998).

[7] W. Gao, W. Wang, M. R. Farahani, Topological indices study of molecular structure in anticancer drugs. Journal of Chemistry 10 (2016). DOI: 10.1155/2016/3216327.

[8] A. Ghorbani, M. A. Hosseinzadeh, Computing $\mathrm{ABC}_{4}$ index of nanostar Dendrimers, Optoelectronics and $\mathrm{Ad}$ vanced Materials-Rapid Communications, 4, 14191422 (2010).

[9] A. Graovac, M. Ghorbani, M. A. Hosseinzadeh, Computing fifth geometric-arithmetic index for nanostar Dendrimers, J. Math. Nanosci., 1, 33-42 (2011).

[10] I. Gutman, K. C. Das, The first Zagreb index 30 years after. MATCH Commun. Math. Comput. Chem, 50, 8392 (2004).

[11] I. Gutman, N. Trinajstić, Graph theory and molecular orbital's., Total-electron energy of alternant hydrocarbons. Chemical Physics Letters, 17, 535-538 (1972).

[12] W. Gao, M. R. Farahani, L. Shi, Forgotten topological index of some drug structures, Acta Medica Mediterranea, 32, 579-585 (2016).

[13] W. Gao, M. R. Farahani, Degree-based indices computation for special chemical molecular structures using edge dividing method, Applied Mathematics and Nonlinear Sciences, 1 (1), 94-117 (2015).

[14] W. Gao, W. Wang, M. K. Jamil, M. R. Farahani, Electron energy studying of molecular structures via forgotten topological index computation, Journal of Chemistry, (2016). DOI:10.1155/2016/1053183.

[15] W. Gao, W. F. Wang, M. K. Jamil, R. Farooq, M. R. Farahani, Generalized atom-bond connectivity analysis of several chemical molecular graphs, Bulgarian Chemical Communications, 48 (3), 543-549 (2016).

[16] W. Gao, M. K. Siddiqui, M. Imran, M. K. Jamil, M. R. Farahani, Forgotten topological index of chemical structure in drugs, Saudi Pharmaceutical Journal, 24, 258264 (2016)
[17] D. H. Baker, Cupric oxide should not be used as a copper supplement for either animals or humans, American Society for Nutritional Sciences. J. Nutr., 129, 2278 2279 (1999).

[18] S. Hayat, M. A. Malik, M. Imran, Computing topological indices of honey-comb derived networks, Romanian Journal of Information Science and Technology, 18, 144-165 (2015).

[19] S. Hayat, M. Imran, Computation of certain topological indices of nanotubes covered by $\mathrm{C}_{5}$ and $\mathrm{C}_{7}, J$. Comput. Theor. Nanosci., 12 (4), 533-541 (2015).

[20] S. Hayat, M. Imran, Computation of topological indices of certain networks, Appl. Math. Comput. 240, 213-228 (2014).

[21] Y. Hu, X. Li,Y. Shi, T. Xu, I. Gutman, On molecular graphs with smallest and greatest zero ${ }^{\text {th }}$-order general Randić index, MATCH Commun. Math. Comput. Chem., 54, 425-434 (2005).

[22] M. Imran, S. Hayat, On computation of topological indices of Aztec diamonds, Sci. Int. (Lahore), 26 (4), 14071412 (2014).

[23] I. Iakovidis, I. Delimaris, S. M. Piperakis, Copper and its complexes in medicine: A Biochemical Approach, $\mathrm{Mo}$ lecular Biology International, (2011). DOI:10.4061/2011/594529.

[24] X. Li, I. Gutman, Mathematical aspects of Randić type molecular structure descriptors. Mathematical chemistry monographs No. 1, Kragujevac, 2006.

[25] A. Q. Baig, M. Imran, H. Ali, On topological indices of polyoxide, polysilicate, DOX, and DSL networks, $\mathrm{Ca}$ nadian Journal of Chemistry, 93, 730-739 (2015).

[26] M.R. Farahani, Computing fourth atom bond connectivity index of V-phenylenic nanotubes and nanotori. Acta Chimica Slovenica, 60, (2), 429-432 (2013).

[27] B. Rajan, A. William, C. Grigorious, S. Stephen, On certain topological indices of silicate, honeycomb and hexagonal networks, J. Comp. and Math. Sci. 3(5), 530535 (2012).

[28] M. Randić, On characterization of molecular branching, J. Amer. Chem. Soc., 97 (23), 6609-6615 (1975).

[29] S. Ramakrishnan, J. Senbagamalar, J. B. Babujee, Topological indices of molecular graphs under specific chemical reactions, International Journal of Computing Algorithm, 2, 224-234 (2013).

[30] P. Szymanski, T. Fraczek, M. Markowicz, Elzbieta Mikiciuk-Olasik, Development of copper based drugs, radiopharmaceuticals and medical materials, Biometals, 25, 1089-1112 (2012).

[31] D. Vukičević, B. Furtula, Topological index based on the ratios of geometrical and arithmetical means of endvertex degrees of edges, J. Math. Chem., 46, 1369-1376 (2009).

[32] H. W. Richardson, Copper Compounds, in Ullmann's Encyclopedia of Industrial Chemistry, Wiley-VCH, Weinheim. (2002). DOI:10.1002/14356007.a07 567.

[33] H. Wiener, Structural determination of paraffin boiling points, J. Amer. Chem. Soc., 69, 17-20 (1947). 
